\title{
ANALISIS DAN PERANCANGAN SISTEM REPLIKASI DATABASE MYSQL DENGAN MENGGUNAKAN VMWARE PADA SISTEM OPERASI OPEN SOURCE
}

\author{
Halim Maulana \\ Magister Teknik Informatika, Universitas Sumatera Utara \\ Jl. Universitas No.9A Kampus USU, Medan, Sumatera Utara-Indonesia
}

\begin{abstract}
Abstrak- Replikasi adalah suatu teknik untuk melakukan copy dan pendistribusian data dan objek-objek database dari satu database ke database lain dan melaksanakan sinkronisasi antara database sehingga konsistensi data dapat terjamin. Replikasi database dapat digunakan apabila sebuah organisasi atau perusahaan didukung oleh hardware dan aplikasi software dalam sebuah sistem yang terdistribusi melalui koneksi jaringan lokal maupun internet. Aplikasi yang berbeda mempunyai kebutuhan yang berbeda untuk otonomi dan konsistensi data dan pengguna dapat bekerja dengan mengcopy data pada saat tidak terkoneksi kemudian melakukan perubahan untuk dibuat database baru pada saat terkoneksi. Dengan menggunakan Vmware workstation dan Ubuntu server 14.0 yang menyediakan fasilitas simulasi jaringan antar PC meski tidak terpasang Network card maupun hub atau switch. Dengan menggunakan Vmware wokstation dan Ubuntu server ini pula akan dibangun Sistem Replikasi Database.Dengan memanfaatkan sistem replikasi database tersebut setiap client ataupun user dapat saling menggunakan database yang direplikasi dari server, sehingga setiap perubahan dari sisi server maupun client akan dapat langsung tersimpan pada seluruh sistem.
\end{abstract}

Keywords - Replication Database, Vmware, Ubuntu Server, MySQL.

\section{PENDAHULUAN}

Dalam paradigma baru di era teknologi informasi, basis data menjadi komponen dasar dari semua aplikasi-aplikasi dalam sebuah sistem informasi. Berbagai produk basis data kini tersedia dipasaran lengkap dengan perangkat pendukung untuk pembuatan program-programnya. Program-program tersebut digunakan terutama untuk menyajikan informasi yang diperlukan dan untuk menangkap informasi dari pengguna dengan kata lain untuk berinteraksi dengan pengguna.

Dalam siklusnya, sebuah sistem informasi akan mengalami saat dimana ia akan digantikan oleh sistem yang baru karena terjadinya perkembangan kebutuhan pengguna tidak lagi dapat dipenuhi, atau karena berbagai alasan lain. Jika ini terjadi maka ada kemungkinan seluruh perangkat pendukungnya baik basis data maupun program-programnya pun akan diganti.

\section{LANDASAN TEORI}

\section{A. Sistem}

Sistem didefinisikan sebagai suatu set komponen yang saling terkait dengan batasan yang jelas dan bekerja sama untuk mencapai tujuan dengan menerima input dan memproduksi output dalam proses transformasi yang terorganisir [1].

\section{B. Basis Data}

Basis data adalah kumpulan terpadu dari elemen data logis yang saling berhubungan. Basis data mengonsolidasi banyak catatan yang sebelumnya disimpan dalam file terpisah. Basis data adalah kumpulan file-file yang saling berelasi,maka dari itu dapat disimpulkan basis dataadalah koleksi dari data terkait yang formatnya standar dan dirancang untuk bisa diakses beberapa pengguna [2].

\section{Database Management System (DBMS)}

DBMS merupakan sebuah sistem software yang memungkinkan pengguna untuk menjelaskan, membuat, memelihara dan mengontrol akses dalam database. DBMS juga merupakan peranti lunak khusus untuk membuat dan memelihara basis data dan memungkinkan aplikasi bisnis individu mengambil data yang dibutuhkan tanpa harus membuat basis data berbeda.Maka dari itu dapat disimpulkan bahwa DBMS adalah seperangkat program komputer yang mengendalikan pembuatan, pemeliharaan, dan penggunaan database organisasi [3].

\section{Replikasi Database}

Replikasi adalah suatu teknik untuk melakukan copy dan pendistribusian data dan objek-objek database dari satu database ke database lain dan melaksanakan sinkronisasi antara database sehingga konsistensi data dapat terjamin. Dengan menggunakan teknik replikasi ini, data dapat didistribusikan ke lokasi yang berbeda melalui koneksi jaringan lokal maupun internet. Replikasi juga memungkinkan untuk mendukung kinerja aplikasi, penyebaran data fisik sesuai dengan penggunaannya, seperti pemrosesan transaksi online dan DSS (Desiscion Support System) atau pemrosessan database terdistribusi melalui beberapa server [4][5][6]. 


\section{E. Manfaat Replikasi Database}

Keuntungan replikasi tergantung dari jenis replikasi tetapi pada umumnya replikasi mendukung ketersediaan data setiap waktu dan dimanapun diperlukan.Adapun keuntungan lainnya adalah[7][8][9]:

1. Memungkinkan beberapa lokasi menyimpan data yang sama. Hal ini sangat berguna pada saat lokasi-lokasi tersebut membutuhkan data yang sama atau memerlukan server yang terpisah dalam pembuatan aplikasi laporan.

2. Aplikasi transaksi online terpisah dari aplikasi pembacaan seperti proses analisis database secara online, data smarts atau data warehouse.

3. Memungkinkan otonomi yang besar. Pengguna dapat bekerja dengan meng-copy data pada saat tidak terkoneksi kemudian melakukan perubahan untuk dibuat database baru pada saat terkoneksi.

4. Data dapat ditampilkan seperti layaknya melihat data tersebut dengan menggunakan aplikasi berbasis Web.

5. Meningkatkan kinerja pembacaan.

6. Penggunaan replikasi sebagai bagian dari strategi standby server.

7. Menyembunyikan perbedaan-perbedaan antara layanan replicated dan non-replicated.

\section{F. $M y S Q L$}

MySQL adalah salah satu jenis database server yang sangat terkenal. Kepopulerannya disebabkan Mysqlmenggunakan SQL sebagai bahasa dasar untuk mengakses databasenya. Mysql termasuk jenis RDBMS (Relational Database Management System). Pada Mysql, sebuah database mengandung satu atau sejumlah tabel. Tabel terdiri atas sejumlah baris dan setiap baris mengandung satu atau beberapa kolom. Untuk mengelola database Mysql ada beberapa cara yaitu melalui prompt DOS (tool command line) [10][11].

\section{METODE PENELITIAN}

Adapun langkah-langkah dalam metode waterfall dalam penelitian ini adalah sebagai berikut :

1. Tahapan Analisa Kebutuhan, Mengumpulkan kebutuhan-kebutuhan yang diperlukan dalam membangun sistem replikasi database kemudian melakukan analisa terhadap kebutuhan tersebut untuk mencari solusi dengan mengimplementasikannya kedalam server yang akan dibangun. Penulis melakukan pengumpulan kebutuhan dengan melakukan observasi dan studi literatur tentang Database Management system dan Database Replication system serta bagian-bagian yang terdapat didalamnya.

2. Tahap Perancangan Sistem, pada tahap ini di lakukan perancangan topologi jaringan yang akan digunakan pada pembangunan sistem replikasi database.
3. Implemetasi Dan Pengujian Unit, merupakan proses mengkonversi dari tahap perancangan sistem kedalam bentuk sistem berdasarkan dengan data-data yang telah di pelajari dari studi literatur dan observasi yang telah dilakukan. Dan akan dilakukan pengujian terhadap sistem yang telah dibangun untuk mengetahui apakah penelitian berhasil atau tidak.

4. Pengujian Sistem, setelah implementasi sistem telah berhasil di setiap server yang dibangun, di tahap ini dilakukan pengujian pada apakah sistem replikasi berjalan dengan baik atau tidak.

5. Maintenance, pada tahap ini sistem telah berhasil di bangun. Pemeliharan meliputi perbaikan kekurangan-kekurangan ataupun error saat pengembangan dan pengembangan sistem.

\section{A. Perancangan Sistem}

Implementasidan pembahasan ini secara garis besarsistem replikasi databaseyang akan dibuat ini nantinya akan berupa simulasi jaringan yang bersifat virtual yang di implementasikan di dalam sebuah komputer/laptop dengan telah terinstall aplikasi Vmware Workstation 9.0. Dan jumlah server yang akan dibangun ini nantinya akan terdapat sejumlah satu buah yang diinstall secara virtual didalam virtual machine Vmware Workstation 9.0. Implementasi sistem replikasi database pada Tugas Akhir ini menggunakan sistem operasi Ubuntu Server. Dalam membangun sistem replikasi database Mysql ini ada beberapa hal yang harus di persiapkan yaitu :

1. Master

2. Slave

3. MysqlDump

4. My.ini/My.cnf

\section{B. Perancangan Topologi Jaringan}

Seluruh komponen dikonfigurasi sesuai dengan kelompok yang telah ditetapkan. Konfigurasi komponen-komponen tersebut sesuai dengan desain sistem yang akan dikerjakan seperti pada gambar dibawah ini

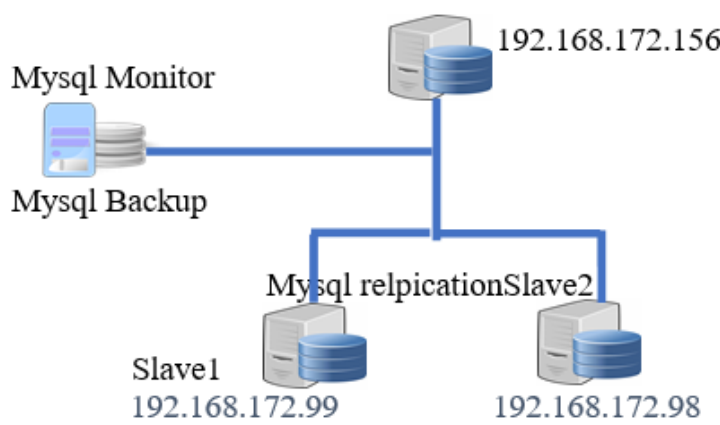

Gbr.1 Arsitektur Web Services

Topologi ini sebuah master Mysql di kembangkan untuk mendukung semua aplikasi termasuk session 
Management, content Management dan untuk pencarian database. Untuk meyakinkan master Mysql dapat mendedikasikan sumber dayanya untuk melayani slave-slave dalam hal proses pendistribusian data. Database di replikasikan kepada dua slave, satu untuk menangani backup dan yang lainnya untuk menganalisa hasil backup. Implementasi di lakukan dengan 1 server, dan yang lainnya sebagai slave. Server 1 bertindak sebagai master yang berfungsi sebagai master replikasi, database yang yang akan di replikasi tersimpan di sini terlebih dahulu sebelum di replikasikan ke perangkat lain dan juga menyimpan hasil backup atau log-bin dari proses replikasi yang sedang berlangsung.

\section{HASIL DAN PEMBAHASAN}

Implementasi dilakukan berdasarkan analisis dan perancangan yang telah dibuat. Setelah implementasi selesai, maka selanjutnya akan dilakukan pengujian apakah sistem sudah berhasil berjalan dengan baik atau tidak, dan memastikan apakah server yang digunakan sebagai server sudah bekerja dengan baik seperti yang telah di rancang. Adapun tahapan-tahapan yang akan dilakukan dalam pembuatan sistem replikasi database ini adalah sebagai berikut:

1. Proses Instalasi server

Server yang digunakan dalam pembuatan sistem ini adalah ubuntu server yang menggunakan versi stabilnya yaitu 12.04. Dimana server ini yang akan menjadi pusat replikasi atau master yang akan di replikasikan kepada slave yang terkoneksi kedalam jaringan.

2. Konfigurasi server/slave

Setelah semua yang dibutuhkan telah dipasangkan ke server maka akan dilakukan konfigurasi untuk server seperti hostname dan ip address.

3. Instalasi paket-paket

Dalam instalasi server, biasanya hanya akan memasang aplikasi-aplikasi standar, sehingga untuk kepentingan replikasi ini maka akan di tambahkan aplikasi tambahan yang akan diinstal, yaitu Mysql server edition version 5.5, php , apache server, serta myphp admin.

4. Instalasi dan konfigurasi sistem replikasi database. Pada tahap ini adalah instalasi server yang bertindak sebagai master yang berfungsi sebagai pusat replikasi yang menyediakan database yang akan direplikasikan ke slave dalam network. Sebelum tahap instalasi dilakukan, Vmware Workstation harus sudah diinstall di komputer host. Setelah itu buka software VMware Workstation 9.0.

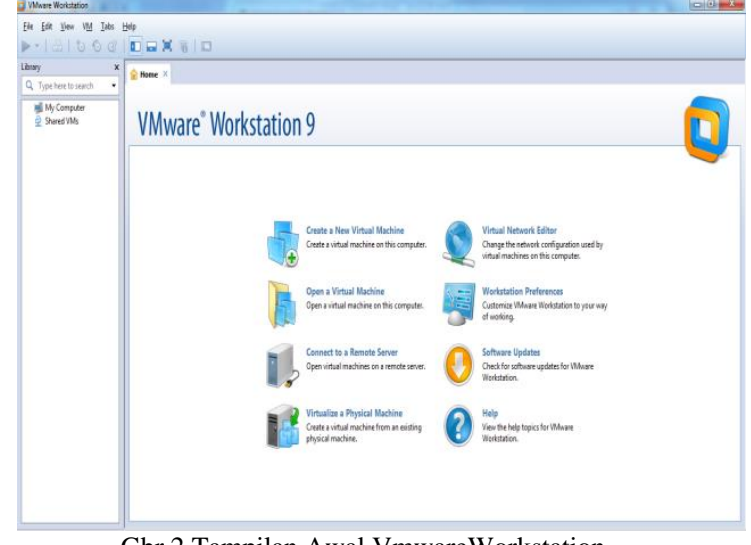

Gbr.2 Tampilan Awal VmwareWorkstation

Pada gambar 2 menjelaskan untuk membuat New Virtual Machine, pilih menu file $>$ New Virtual Machine pada window Vmware Workstation 9.0.

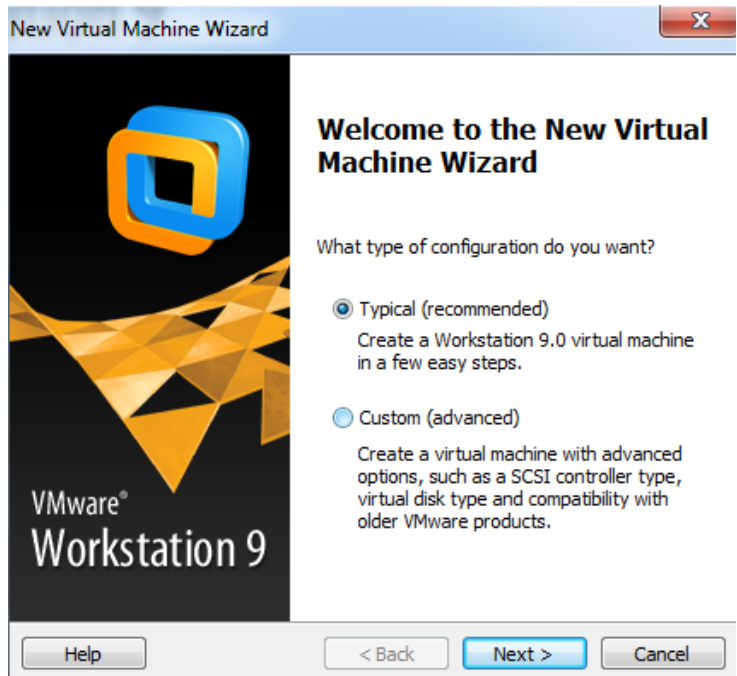

Gbr.3 Tampilan Awal VmwareWorkstation

Pada gambar 3 memperlihatkan tampilan padapop-up window yang muncul pilih tipe konfigurasi Typical.

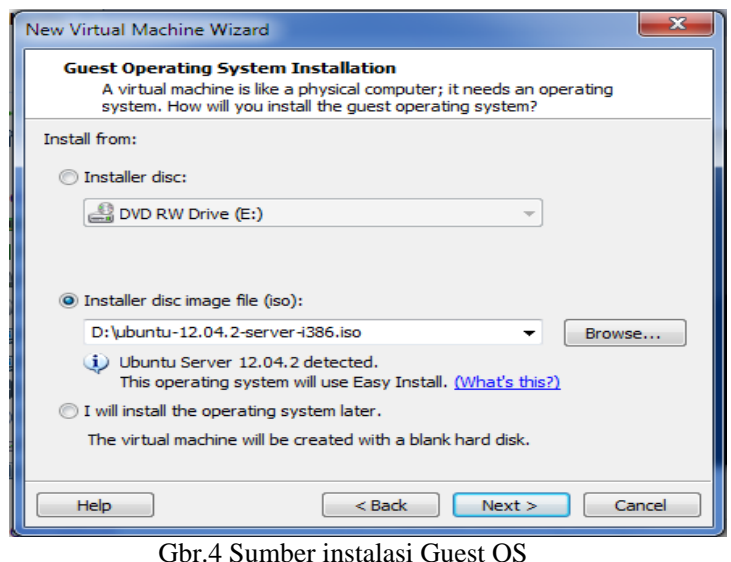

pada gambar 4 window tersebut akan diminta sumber instalasi cd atau lokasi disc image file (iso) atau dapat menginstal sistem operasi nanti, disini akan dipilih 
installer disc image file, karena akan langsung menginstal sistem operasinya, lalu klik next.

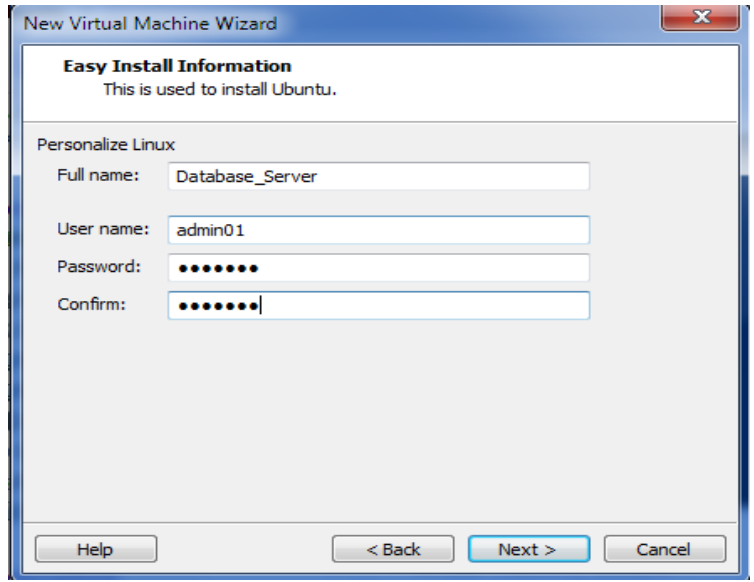

Gbr.5 Informasi Guest OS

Pada gambar tersebut akan diminta informasi dari sistem operasi virtual yang akan diminta seperti username dan password, setelah itu lalu klik next.

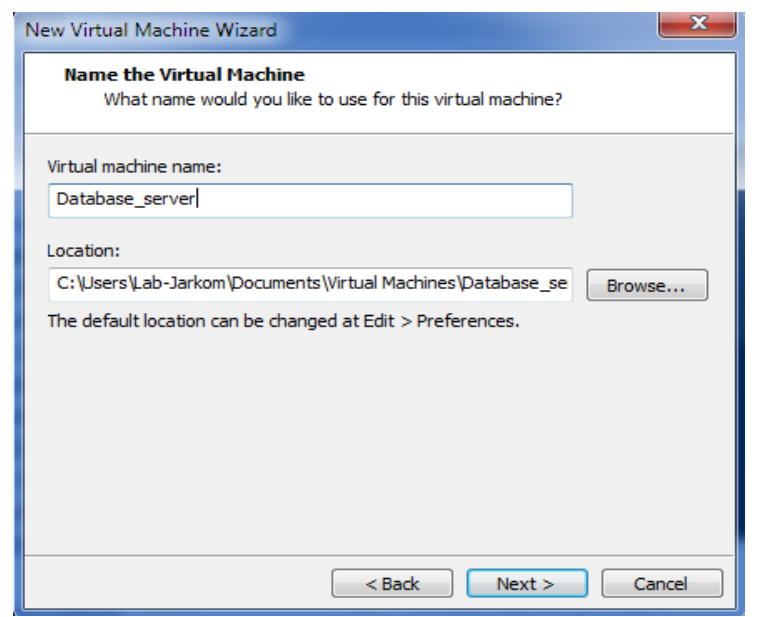

Gbr.6 Lokasi Dan Nama Virtual Machine

Setelah itu akan munculwindow berikutnya, yang berisi nama Virtual Machine dan lokasi dimana virtual machine itu disimpan. Dan pada window berikutnya akan ditanyakan ukuran space yang akan dijadikan virtual disk sebagai hardisk dari sistem operasi virtual tadi lalu klik next dan lalu klik finish seperti yang terlihat pada gambar 6 .

\begin{tabular}{l} 
New Virtual Machine Wizard \\
\hline Specify Disk Capacity \\
How large do you want this disk to be?
\end{tabular}

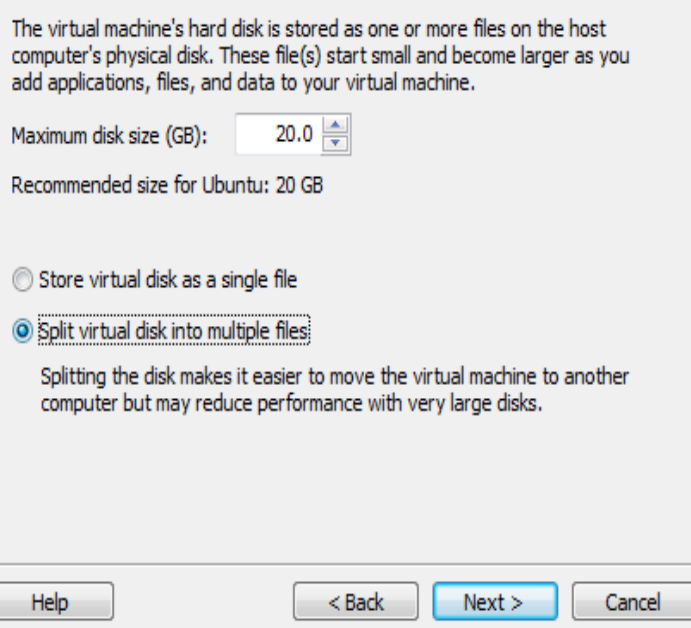

Gbr.7 Ukuran Hardisk Guest OS

Pada gambar 7 memperlihatkan tampilan untukserver pertama ini akan dialokasikan sebesar 20GB sebagai hardisknya yang akan disimpan dengan metode penyimpanan yang dipilih adalah Split disk into multiple files, yang berarti file hardisk virtual akan disimpan dalam file yang dipecah menjadi beberapa bagian, sehingga jika akan di pindahkan, akan jauh lebih mudah daripada memindahkan file hardisk virtual yang berukuran yang sangat besar.

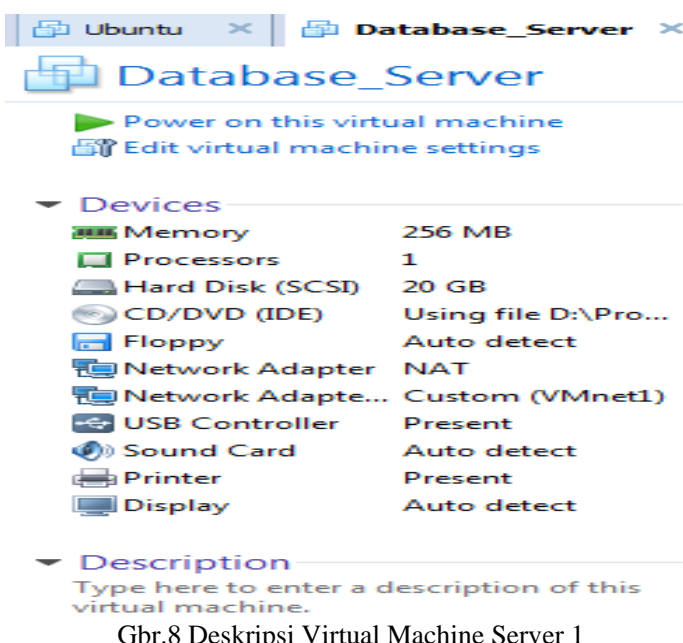

Setelah New Virtual Machine berhasil dibuat, klik pada Power on this Virtual machine maka virtual machine akan berjalan seperti pada gambar 8 . 


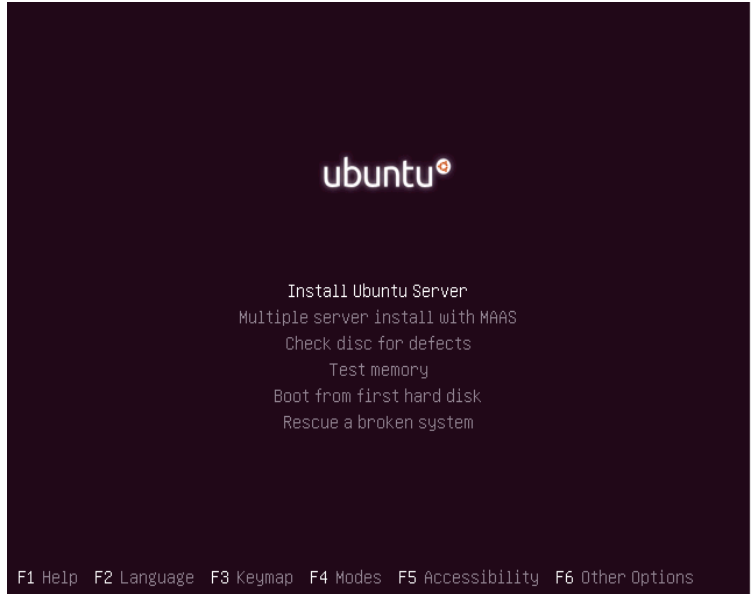

Gbr.9 Tampilan Awal Instalasi Server 1

Pada gambar 9 dapat terlihat pilihan instalasi dari file iso dari ubuntu yang terdeteksi otomatis oleh virtual machine, pada pilihan tersebut akan dipilih "Install Ubuntu Server" lalu enter.

\section{A. Pengujian}

Setelah semua proses konfigurasi selesai dilakukan, masuk kepada tahap pengujian dimana proses pengujian sistem replikasi database dilakukan. Proses pengujian sistem replikasi database ini menggunakan 2 buah sistem operasi yang bersifat virtual menggunakan VMware. Adapun sistem operasi yang digunakan yaitu ubuntu server. Berikut hasil pengujian sistem yang telah dibangun, login ke master :

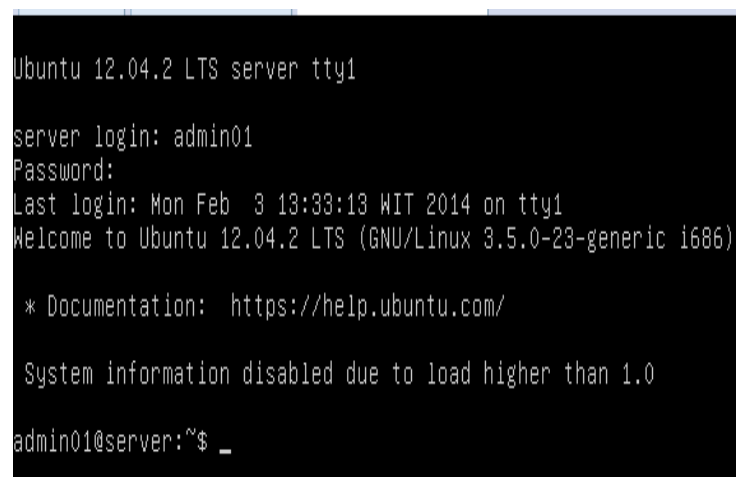

Gbr.10 Login Master

Terlihat pada gambar 10 login master dengan username admin01, dan password admin01 setelah itu masuk ke mysql shell.

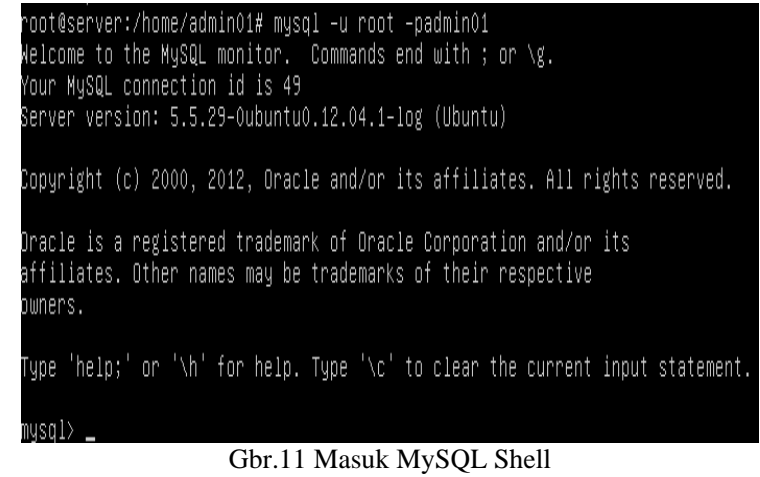

Setelah masuk ke dalam mysql master kita perlu memilih database yang kita gunakan untuk di replikasi (gambar 11 tampilan masuk Mysql shell).

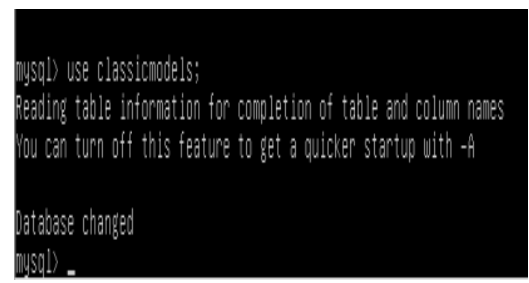

Gbr.12 Memilih Database Aktif

Sampai pada proses seperti yang digambarkan pada gambar 12, langkah berikut nya beralih kepada slave master, login terlebih dahulus ke dalam slave.

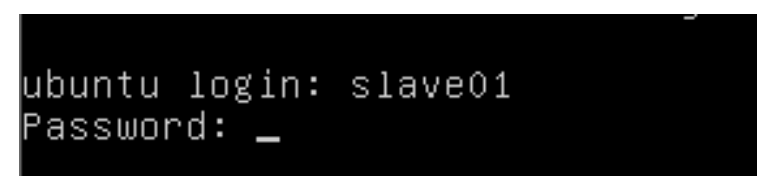

Gbr.13 Login Slave

Pada gambar 13 memperlihatkan tampilan login ke dalam sistem slave, karena kita membutuhkan kedua sistem ini berjalan secara bersamaan untuk melakukan pengujian sistem replikasi. Login sistem slave dengan username "slave01" dan password "slave01". Setelah berhasil masuk ke dalam sistem slave, Ubah database yang aktif menjadi sama seperti yang aktif dalam master.

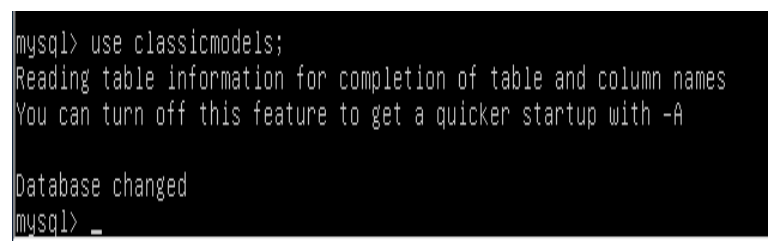

Gbr.14 Mengganti Database Aktif Slave

Setelah kedua sistem menggunakan database yang aktif, berikut kita coba melihat status tabel dari database pada kedua sistem. Berikut daftar tabel yang terdapat pada database classicmodels pada sistem master. 


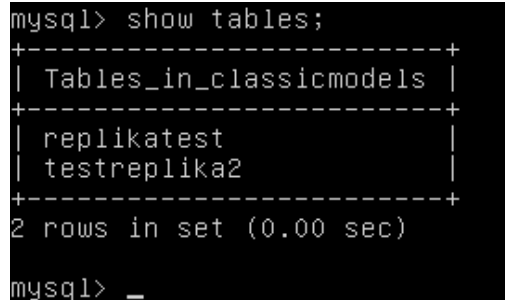

Gbr.15 Tabel Master

Bandingkan tabel master diatas dengan yang ada pada sisi slave seperti yang terlihat pada gambar 15 dan 16 .

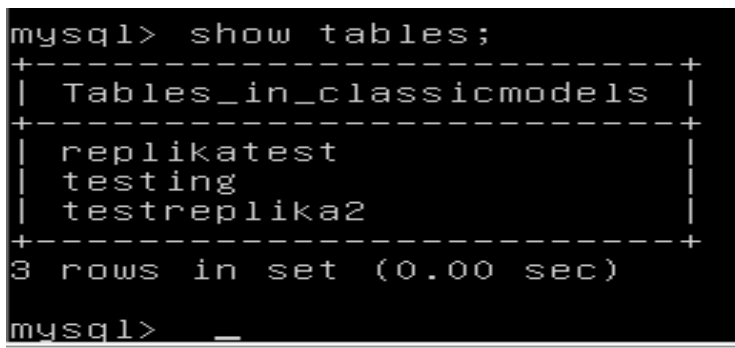

Gbr.16 Tabel Slave

Dari gambar diatas kedua sistem memiliki database yang sama dan tabel yang sama, pada tahap ini tabel kedua sistem memang sengaja dibuat sama untuk dapat lebih mudah mengetahui proses replikasi dapat berjalan dengan baik atau tidak.

Sebagai pengujian akan mencoba menambahkan sebuah tabel baru pada master dengan perintah seperti padda gambar 18 dibawah ini :

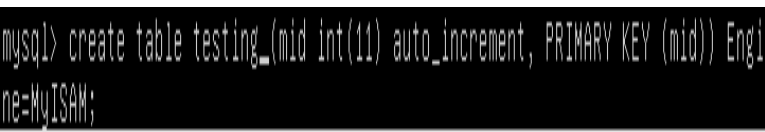

Gbr.17 Menambahkan Tabel pada master

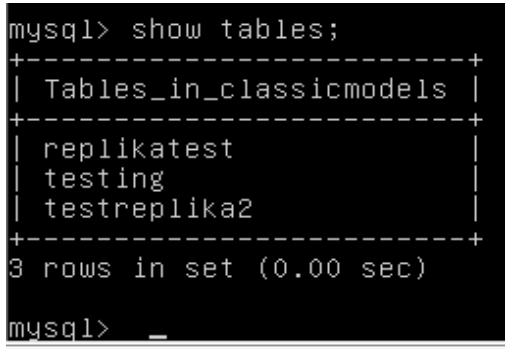

Gbr.18 Tabel Pada Master

Setelah dilakukan penambahan tabel "testing" pada sisi master yang terlihat pada gambar diatas yaitu gambar 18 maka,sekarang langsung kita lihat pada sisi slave yang digambarkan pada gambar 19, tanpa ada perintah apapun kita ketikkan perintah untuk menampilkan tabel.

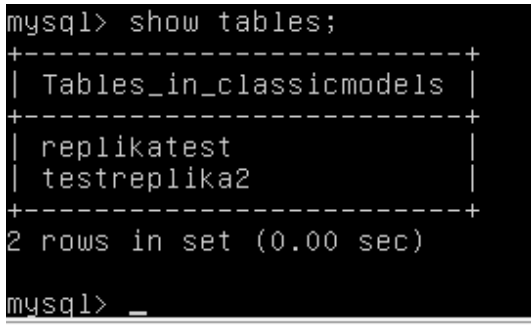

Gbr.19 Tabel pada slave

Dari gambar di atas terlihat ada satu tambahan tabel yaitu tabel "testing" dapat diperhatikan, pada sisi slave kita tidak ada melakukan percobaan untuk menambahkan tabel "testing" tetapi tabel testing sudah ada secara otomatis. Dapat disimpulkan bahwa proses replikasilah yang menambahkannya secara otomatis pada databaseslave dengan menyalin perubahan yang ada pada master dan langsung di salin kepada slave.

\section{KESIMPULAN}

Dari hasil pengujian dan implementasi Perancangan Sistem Replikasi Database Pada Vmware Dengan Ubuntu Server dapat di simpulkan bahawa sistem replikasi database dapat berjalan dengan baik pada Vmware Workstation dengan ubuntu server 14.0 dan dengan menggunakan sistem replikasi database dapat mempermudah, mempercepat dan menghemat baik dari segi proses maupun waktu dalam suatu project.

\section{REFERENS}

[1] Anonymous. (2008). Sistem, Diakses pada tanggal 12 April2008 dari: http://id.wikipedia.org/wiki/Sistem.

[2] [Cahyono,Setiyo.(2009),Pemrograman Database Menggunakan MySQL Dan Java.Bandung

[3] Connolly,Thomas dan Carolyn Begg,(2010), Database Systems A Practical Aprroach to Design, Implementation, and Management 4 th Edition, Pearson Education Limited,Harlow

[4] Yu Ping, Hu Hong-Wei and Zhou Nan, "Design and implementation of a MySQL database backup and recovery system," Intelligent Control and Automation (WCICA), 2014 11th World Congress on, Shenyang, 2014, pp. 5410-5415.

[5] K. Xiang, "An improvement in MySQL cluster in e-commerce scenarios," Information Technology and Electronic Commerce (ICITEC), 2014 2nd International Conference on, Dalian, 2014, pp. 286-289.USA: Abbrev. of Publisher, year, ch. $x$, sec. $x$, pp. $x x x-x x x$.

[6] E. Bautista and N. L. Serna, "An MDE-based graphical tool for the validation of MySQL replication models," Computing Conference (CLEI), 2015 Latin American, Arequipa, 2015, pp. $1-12$.

[7] Schwartz, B., Zaitsew, P \& Tkachenko, V. High Performance MySQL. O'Reily Media, Inc. 2012

[8] Bell, C., Kindahl, M \& Thalmann, L. MySQL High Availability: Tools for Building Robust Data Centers 2nd Edition, O’Reilly Media. 2014.

[9] Dyer, R.J.T. Learning MySQL and MariaDB Heading in the Right Direction with MySQL and MariaDB. O'Reilly Media. 2015.

[10] Butler, T \& Yank, K. PHP \& MySQL: Novice to Ninja, 6th Edition. SiitePoing. 2016.

[11] Boronczyk, T. Jump Start MySQL. SitePoint. 2015 